\title{
Comparison of five tests used in diagnosis of neonatal bacteraemia
}

\author{
$\mathrm{P}$ KITE,${ }^{*} \mathrm{M}$ R MILLAR, ${ }^{*} \mathrm{P}$ GORHAM,$\dagger$ AND P CONGDON $\dagger$ \\ Department of *Medical Microbiology and Regional Neonatal Unit, The General Infirmary, Leeds
}

SUMmARY The neutrophil count, immature:total neutrophil ratio, $\mathrm{C}$ reactive protein assay, nitroblue tetrazolium test and an acridine orange leucocyte cytospin test were evaluated for the diagnosis of neonatal bacteraemia. The acridine orange leucocyte cytospin test gave the highest specificity and positive predictive accuracy, but was less sensitive than the neutrophil count, $\mathrm{C}$ reactive protein assay or nitroblue tetrazolium test, particularly for the diagnosis of bacteraemia caused by coagulase negative staphylococci. No single test gave the sensitivity, specificity, and positive predictive accuracy of the combined results of the acridine orange leucocyte cytospin, $\mathrm{C}$ reactive protein, and nitroblue tetrazolium tests.

Bacteraemia is a common cause of morbidity and mortality among neonates in intensive care units, ${ }^{1}$ but the clinical signs are often non-specific. ${ }^{2}$ It has been suggested that a combination of haematological and biochemical tests may provide a more rapid and accurate diagnosis of bacteraemia than conventional microbiological methods ${ }^{34}$ and the use of a 'sepsis screen' may reduce the amount of antibiotics used. ${ }^{5}$

We selected five tests including the acridine orange leucocyte cytospin test that could be performed rapidly and economically, and adapted them for use with small amounts of blood. We report an evaluation of these tests in neonates in a regional referral neonatal unit with suspected bacteraemia.

\section{Patients and methods}

The regional neonatal unit admits about 500 babies each year with both medical and surgical illnesses from this and other units in West Yorkshire. More than $60 \%$ of the admissions to the regional neonatal unit are premature neonates with the respiratory distress syndrome. Blood, cerebrospinal fluid, and urine were collected from all neonates with suspected bacteraemia. Clinical signs of bacteraemia included unstable temperature, apnoea, bradycardia, poor peripheral perfusion, or hypotension.

Blood was collected by arterial or venous puncture after skin disinfection with $70 \%$ isopropyl alcohol or povidone iodine. Up to $2 \mathrm{ml}$ was divided into three containers as follows: one $0.5 \mathrm{ml}$ sample was anticoagulated with edetic acid (final concentra- tion $1.5-2 \mathrm{mg} / \mathrm{l}), 0.5 \mathrm{ml}$ was placed in a tube without anticoagulant and $0 \cdot 5-1 \mathrm{ml}$ was inoculated aseptically into $80 \mathrm{ml}$ of broth (Signal medium BC 102, Oxoid Ltd, Basingstoke). An indicator was inserted through the rubber seal ${ }^{6}$ and the broth culture incubated at $37^{\circ} \mathrm{C}$ on a Denley (prototype) continuous shaker at $160 \mathrm{rpm}$ for 4-18 hours, it was then left in the incubator for up to 10 days. Bottles with signs of bacterial growth and all bottles after 48 hours of incubation were subcultured by inoculation of $0.1 \mathrm{ml}$ aliquots on to heated blood agar and $5 \%$ horse blood agar plates, which were incubated at $37^{\circ} \mathrm{C}$ in $5 \%$ carbon dioxide and at $37^{\circ} \mathrm{C}$ anaerobically, respectively, for up to 48 hours. Isolates from the blood cultures were identified using conventional microbiological techniques. ${ }^{7}$ Coagulase negative staphylocorci were defined as catalase positive, coagulase negative, deoxyribonuclease negative Gram positive cocci.

The sample containing edetic acid was used for the neutrophil count, immature:total neutrophil ratio, nitroblue tetrazolium test, and the acridine orange leucocyte cytospin test. The total nucleated cell count was made on a Coulter counter and a differential cell count from a Giemsa stained blood film gave the immature:total neutrophil ratio. ${ }^{8}$ An age adjusted normal range ${ }^{9}$ was used to assess the neutrophil counts, and neutropenia or neutrophilia were considered abnormal. A normal range of up to 0.2 was used for the immature:total neutrophil ratio. $^{4}$

The nitroblue tetrazolium test was done by a modified cytocentrifuge technique. ${ }^{10} 50 \mu \mathrm{l}$ of blood 
containing edetic acid was added to $100 \mu \mathrm{l}$ of $0 \cdot 15 \mathrm{M}$ phosphate buffered saline $(\mathrm{pH} 7 \cdot 2)$ containing $0.075 \%(\mathrm{w} / \mathrm{v})$ nitroblue tetrazolium in polystyrene tubes. The mixture was incubated at $37^{\circ} \mathrm{C}$ for 20 minutes, and then for a further five minutes at room temperature. Red cells were lysed by the addition of $1.2 \mathrm{ml}$ of hypotonic formal saline $(10 \%$ formalin containing $0 \cdot(025 \mathrm{M}$ sodium chloride). When red cell lysis was complete (usually after one minute), $2.8 \mathrm{ml}$ of $0 \cdot 2 \mathrm{M}$ sodium chloride was added, and after mixing the tubes were centrifuged at $258 \mathrm{~g}$ for five minutes. The supernatant was discarded by inversion and $50 \mu \mathrm{l}$ of $22 \%(\mathrm{w} / \mathrm{v})$ bovine albumin (Ortho Diagnostics, New Jersey, USA) was added to resuspend the deposit that was then prepared as a cellular monolayer with a Shandon 2 cytospin at $1000 \mathrm{rpm}$ for five minutes. The cytospin preparation was heat fixed at $70^{\circ} \mathrm{C}$ for two minutes and stained with $0 \cdot 15 \%(\mathrm{w} / \mathrm{v})$ aqueous rhodanile blue dye that had been passed through an $0 \cdot 2 \mu \mathrm{m}$ cellulose acetate filter to remove any deposit. Stained slides were examined by light microscopy at a magnification of 400. The percentage of 100 neutrophils containing nitroblue tetrazolium formazan gave the nitroblue tetrazolium score, with a normal range of up to $13 \% .{ }^{11}$ The metabolic integrity of the neutrophils was assessed using phorbol myristic acid. ${ }^{12}$

The acridine orange leukocyte cytospin test was used to detect bacteria in neutrophils from whole blood. The test was performed by adding $50 \mu \mathrm{l}$ of acridine orange $(100 \mathrm{mg} / \mathrm{l}$ in $0 \cdot 15 \mathrm{M}$ sodium chloride) to $50 \mu \mathrm{l}$ of whole blood containing edetic acid in polystyrene tubes. Red cells were lysed and a cellular monolayer prepared as for the nitroblue tetrazolium test. The cytospin slide preparations were heat fixed and then examined by ultraviolet microscopy using a rhodamine filter set at a magnification of 1000 . Intracellular bacteria were coloured bright red against a dull red background. The presence of bacteria was confirmed with a duplicate cytospin preparation or by overstaining, the acridine orange leucocyte cytospin preparation with Gram's stain.

A latex agglutination method ${ }^{13}$ was used to screen serum samples for $\mathrm{C}$ reactive protein concentrations of more than $10 \mathrm{mg} / \mathrm{l}$ after dilution of serum $1 / 10$ in $0 \cdot 15 \mathrm{M}$ sodium chloride. $\mathrm{C}$ reactive protein concentrations of more than $10 \mathrm{mg} / \mathrm{l}$ were quantified using an enzyme multiplied immunoassay. ${ }^{14}$

\section{Results}

Two hundred samples of blood were collected from 100 neonates including 68 who had been admitted with prematurity and the respiratory distress syndrome. The mean gestational age of the premature neonates was $30 \cdot 2$ weeks (range 24-35) and the⿳亠丷厂犬. mean birth weight was $1410 \mathrm{~g}$ (range 700-2470). The $\overrightarrow{\vec{F}}$ remaining 32 babies were admitted with a variety of $\stackrel{\text { ? }}{?}$ other surgical and medical diagnoses. One sample of? blood only was collected from. each of 65 of the neonates; the number of samples taken from the other 35 varied from two to 10 .

After making certain that only one sample wase considered from each episode of suspected bacter- $\overrightarrow{0}$ aemia, ${ }^{5}$ and that contaminated samples had been: excluded, ${ }^{7} 188$ episodes of suspected bacteraemia $\vec{\omega}$ were considered for further study, of which 34 were associated with positive and 154 with negative bloodő cultures. The bacterial species isolated during? episodes of suspected bacteraemia are shown in. table 1 . Twenty one $(62 \%)$ of the 34 blood culture isolates were coagulase negative staphylococci. The proportion of these that were caused by contamina-o tion was not known. There were no episodes of bacterial meningitis during the study. There was onec urinary tract infection that was associated with Escherichia coli septicaemia.

The sensitivity, specificity, and positive predictive $\vec{\infty}$ accuracy of each test are shown in table 2. The. neutrophil count was abnormal in $24(71 \%)$ of the 340 episodes associated with positive blood cultures, but was also abnormal in $65(42 \%)$ of 154 episodes with negative blood cultures. Though the immature:totalo neutrophil ratio was less often abnormal when the $\mathbb{2}$ blood culture was negative, only $10(29 \%)$ of $34 \vec{\Rightarrow}$ episodes associated with positive blood cultures윽 gave an abnormal immature:total neutrophil ratio. Even after exclusion of coagulase negative staphylococci, eight of 13 episodes were associated with immature:total neutrophil ratios of less than $0 \cdot 12$. 융

The $\mathrm{C}$ reactive protein concentration was less: than $10 \mathrm{mg} / \mathrm{l}$ in $10(29 \%)$ of the 34 episodes associated with positive blood cultures, but in only@i two $(15 \%)$ of 13 episodes after the exclusion of

Table 1 Bacterial species isolated from neonates with episodes of suspected bacteraemia

\begin{tabular}{|c|c|}
\hline Bacterial species & $\begin{array}{l}\text { No of } \\
\text { isolates }\end{array}$ \\
\hline Coagulase negative staphylococci & 21 \\
\hline Pseudomonas aeruginosa & 3 \\
\hline Staphylococcus aureus & 3 \\
\hline Enterococcus faecalis & 2 \\
\hline Enterococcus faecium & 1 \\
\hline Group B streptococcus & 1 \\
\hline Listeria monocytogenes & 1 \\
\hline Escherichia coli & 1 \\
\hline Serratia liquefaciens & 1 \\
\hline Total & 34 \\
\hline
\end{tabular}


Table 2 Sensitivity, specificity, and positive predictive accuracy of tests for the diagnosis of bacteraemia

\begin{tabular}{|c|c|c|c|c|}
\hline & $\begin{array}{l}\text { Sensitivity } \\
(\%)\end{array}$ & $\begin{array}{l}\text { Sensitivity excluding } \\
\text { coagulase negative } \\
\text { staphylococci }(\%)\end{array}$ & $\begin{array}{l}\text { Specificity } \\
(\%)\end{array}$ & $\begin{array}{l}\text { Positive predictive } \\
\text { accuracy }(\%)\end{array}$ \\
\hline Neutrophil count & $70 \cdot 6$ & $84 \cdot 6$ & $57 \cdot 8$ & $27 \cdot 0$ \\
\hline \multicolumn{5}{|l|}{ Immature:total } \\
\hline ncutrophil ratio & $29 \cdot 4$ & $30 \cdot 8$ & $82 \cdot 5$ & $27 \cdot 0$ \\
\hline $\mathrm{C}$ reactive protcin assay & $61 \cdot 8$ & $84 \cdot 6$ & $81 \cdot 2$ & $42 \cdot 0$ \\
\hline Nitroblue tetrazolium test & $76 \cdot 5$ & $100 \cdot 0$ & $70 \cdot 8$ & $36 \cdot 6$ \\
\hline $\begin{array}{l}\text { Acridine orange leucocyte } \\
\text { cytospin test }\end{array}$ & $38 \cdot 2$ & $76 \cdot 7$ & $94 \cdot 2$ & $59 \cdot 1$ \\
\hline $\begin{array}{l}\text { Two or three of } \\
C \text { reactive protein assay, nitroblue } \\
\text { tetrazolium, acridine orange leucocyte } \\
\text { cytospin test positive }\end{array}$ & $61 \cdot 8$ & $92 \cdot 3$ & $90 \cdot 3$ & $56 \cdot 8$ \\
\hline
\end{tabular}

Sensitivity—positive blood cultures with positive test; specificity-negative blood cultures with negative test; positive predictive accuracypositive test with positive blood culture.

coagulase negative staphylococci. Though the nitroblue tetrazolium test was positive in all 13 episodes, $45(29 \%)$ of 154 episodes with negative blood cultures were also associated with positive nitroblue tetrazolium tests. The acridine orange leucocyte cytospin test identified $10(77 \%)$ of 13 episodes of bacteraemia after exclusion of coagulase negative staphylococci and only nine $(6 \%)$ of 154 episodes associated with negative blood cultures gave positive acridine orange leucocyte cytospin tests. The acridine orange leucocyte cytospin test, however, only detected $13(38 \%)$ of 34 episodes associated with positive blood cultures when coagulase negative staphylococci were included.

The $\mathrm{C}$ reactive protein assay, the nitroblue tetrazolium and the acridine orange leucocyte cytospin test gave the highest positive predictive accuracy. Two or three tests were positive in $12(92 \%)$ of the 13 episodes of bacteraemia after exclusion of coagulase negative staphylococci and in $21(62 \%)$ of the 34 episodes associated with positive blood cultures. Coagulase negative staphylococci were isolated from $12(8 \%)$ of the 151 episodes when none or only one of the three tests was positive, and from nine $(24 \%)$ of the 37 episodes when two or more of the tests were positive. The results of total neutrophil counts and immature:total neutrophil ratios did not improve sensitivity, specificity, or positive predictive accuracy when included in three, four, or five test combinations.

In $15(10 \%)$ of the 154 episodes associated with negative blood cultures two or three of the $\mathrm{C}$ reactive protein, nitroblue tetrazolium, and acridine orange leucocyte cytospin tests were positive. These 15 episodes occurred in neonates who had undergone major operations $(n=4)$, had a tracheooesophageal fistula and pneumonia $(n=1)$, and had necrotising enterocolitis $(n=1)$; three babies had received antimicrobial drugs within 24 hours of blood sampling. The remaining six episodes were all associated with positive acridine orange leucocyte cytospin tests, but cultures of the urine and cerebrospinal fluid grew no pathogens.

\section{Discussion}

The neutrophil count, immature:total neutrophil ratio, $\mathrm{C}$ reactive protein assay, nitroblue tetrazolium test, and acridine orange leucocyte cytospin test were evaluated for the diagnosis of bacteraemia in neonates in a regional unit. All these tests could be done within one hour of blood sampling and used a total blood volume of less than one $\mathrm{ml}$.

Many studies have reported the use of total neutrophil count, immature:total neutrophil ratio or $\mathrm{C}$ reactive protein assay for the diagnosis of bacteraemia in neonates. The white cell count is of poor predictive value in neonatal bacteraemia, but the total neutrophil count may be high or low in $80 \%$ of such babies. ${ }^{15}$ Immature:total neutrophil ratios may also be raised in more than $80 \%{ }^{.5-17}$ The poor sensitivity of the immature:total neutrophil ratio in this study may have been the result of sampling at the wrong time, because this unit admits a large proportion of very low birthweight 'high-risk' neonates, and also because the immature:total neutrophil ratio may be less sensitive after the first week of life. ${ }^{18}$ Though a positive blood culture was never associated with a negative nitroblue tetrazolium test, either $\mathrm{C}$ reactive protein assays or nitroblue tetrazolium tests were often positive in association with negative blood cultures.

High specificity and sensitivity have been reported for buffy coat smears prepared from capillary blood and stained with acridine orange. ${ }^{19}$ We 
modified the method to use $50 \mu \mathrm{l}$ of whole blood mixed with edetic acid and were able to identify 10 $(77 \%)$ of 13 episodes of bacteraemia after the exclusion of coagulase negative staphylococci. Positive acridine orange leucocyte cytospin tests with negative blood cultures may have been false positive results or may have resulted from transient bacteraemia.

Infections with coagulase negative staphylococci are rarely associated with neonatal mortality ${ }^{20}$ but coagulase negative staphylococci have replaced Gram negative bacterial species as the commonest isolates from neonatal blood cultures after the first 48 hours of life. ${ }^{2122}$ The high incidence of bacteraemia with coagulase negative staphylococci in premature neonates has been attributed to colonisation of plastic intravascular devices by antibiotic resistant, slime producing strains of coagulase negative staphylococci. ${ }^{23}$ Bacteraemia with coagulase negative staphylococci may be associated with the clinical features of septicaemia, ${ }^{2425}$ so coagulase negative staphylococci isolates were included in this study even though the proportion of isolates of coagulase negative staphylococci in blood cultures that could be attributable to contamination was not known.

Only three $(14 \%)$ of 21 isolates of coagulase negative staphylococci in blood cultures were associated with positive acridine orange leucocyte cytospin tests. The minimum concentration of organisms detectable by the acridine orange leucocyte cytospin technique using $50 \mu \mathrm{l}$ of whole blood was 20 organisms per $\mathrm{ml}$, suggesting lower concentrations for most of the neonates from whose blood cultures coagulase negative staphylococci had been isolated. This may reflect both the low virulence of coagulase negative staphylococci and the proportion of coagulase negative staphylococci contaminants.

The acridine orange leucocyte cytospin test gave the highest specificity and positive predictive accuracy but was less sensitive than neutrophil count, $\mathrm{C}$ reactive protein assay, or the nitroblue tetrazolium test, particularly for the diagnosis of bacteraemia caused by coagulase negative staphylococci. No single test gave the sensitivity, specificity, and positive predictive accuracy of the combined results from the acridine orange leucocyte cytospin test, $\mathrm{C}$ reactive protein assay, and nitroblue tetrazolium test.

Philip ${ }^{5}$ reported a reduction in the use of antibiotics after he started using a combination including estimations of the white cell count, the band:neutrophil ratio, the erythrocyte sedimentation rate, the latex $C$ reactive protein assay and serum haptoglobin concentration for the diagnosis of neonatal sepsis. Many neonatal units use unnecéssary antibiotics. ${ }^{26}$ This study confirms that a combination of tests may improve the accuracy of diagnosis of neonatal bacteraemia. ${ }^{4}$ We intend to follow this study with an evaluation of the influence of this combination of tests on neonatal morbidity and mortality, use of other diagnostic tests, and use of antibiotics in this regional neonatal unit.

\section{References}

1 Goldmann DA, Freeman J, Durbin WA. Nosocomial infection and death in a neonatal intensive care unit. $J$ Infect Dis 1983;147:635-41.

- Siegel JD, McCracken GH. Sepsis neonatorum. $N$ Engl J Med 1981:304:642-7.

${ }^{3}$ Boyle RJ, Chandler BD, Stonestreet BS, Oh W. Early identification of sepsis in infants with respiratory distress. Pediatrics 1978:62:744-50

+ Philip AGS, Hewitt JR. Early diagnosis of neonatal sepsis. Pediatrics 1980;65:1036-41.

5 Philip AGS. Decreased use of antibiotics using a neonatal sepsis screening technique. J Pediatr 1981;98:795-9.

6 King A, Bone G, Philips I. Comparison of radiometrics and gas capture system for blood cultures. J Clin Pathol 1986;39:661-5.

${ }^{7}$ Lennette EH, ed. Manual of clinical microbiology 4th ed. Washington: American Socicty for Microbiology, 1985.

* Manroe BL, Weinberg AG. Rosenfield CR et al. The neonatal $\infty$ blood count in health and disease. I. Reference values for neutrophilic cells. J Pediatr 1979;75:89-98.

"Gregory J. Hey E. Blood neutrophil response to bacterial infection in the first month of life. Arch Dis Child 1972:47: 747-53.

11) Gordon PA, Stuart J, Lee TR, Breeze GR, Pugh RNH. The cytocentrifuge NBT test. J Clin Pathol 1975;28:674-9.

11 Kite P. An evaluation of the nitroblue tetrazolium test and some applications. Leeds: University of Leeds 1980. (Thesis.)

12 Repine J, White JG, Clawson CC. Holmes BM. Effects of phorbol myristate acetate on the metabolism and ultrastructure of neutrophils in chronic granulomatous discase. J Clin Invest 1974;54:83-90.

13 Harris RI, Stone PWC, Hudson AG, Stuart J. C reactive protein rapid assay techniques for monitoring resolution of infection in immunosuppressed patients. J Clin Pathol 1984;37:821-5.

14 Oellerich M. Enzyme immunoassays in clinical chemistry: present status and trends. J Clin Biochem 1980;18:197-208. O

15 Christensen RD, Bradley PP, Rothstein G. The leukocyte left shift in clinical and experimental neonatal sepsis. $J$ Pediatr 1981;98:101-5.

it Kuchler H, Fricher H, Gugler E. La formule sanguine dans le $D$ diagnostic précoce de la septicémic du nouveau-né. Helv을. Paediatr Acta 1976:31:33-46.

17 Manroc BL, Rosenficld CR, Weinberg AG et al. The $\mathcal{N}$ differential leukocyte count in the assessment and outcome of carly-onset neonatal group B streptococcal diseasc. J Pediatr 1977:91:632-7.

is Philip AGS. Detection of neonatal sepsis of late onset. JAMA 1982:247:489-92.

19 Kleiman MB, Reynolds JK, Shreiner RL et al. Rapid diagnosis of neonatal bacteraemia with acridine orange. J Pediatr 1984; 105:419-21.

20 Buetow KC, Klein SW, Lane SB. Septicaemia in premature neonates. The characteristics, treatment and prevention of septicaemia in premature neonates. Am J Dis Child 1965:110: 29-41.

21 Freedman RM, Ingram DL, Gross I et al. A half century of $\mathbb{D}$ neonatal sepsis at York 1928 to 1978. Am J Dis Child $1981: 140: 140-4$

$\frac{10}{20}$


22 Millar MR, Keyworth N, Lincoln C. King B, Congdon P. "Methicillin-resistant" Staphylococcus aureus in a regional neonataology unit. J Hosp Infect 1987;10:187-97.

${ }^{23}$ Hall RT, Hall SL, Barnes WG et al. Characteristics of coagulase-negative staphylococci from infants with bacteraemia. Pediatr Infect Dis 1987;6:377-83.

24 Baumgart S, Hall SE, Campos JM et al. Sepsis with CNS in critically ill newborns. Am J Dis Child 1984:137:461-3.

25 Battisti O. Mitchison R, Davies PA. Changing blood culture isolates in a regional referral intensive care unit. Arch Dis Child 1981:56:775-8

26 Franco JA. Eitzman DV, Baer H. Antibiotic usage and microbial resistance in an intensive care nursery. Am J Dis Child 1973;126:318.

Correspondence to Dr MR Millar, Department of Medical Microbiology, Old Medical School, Leeds LS2 9JT.

Accepted 10 December 1987 